\title{
ICT ADOPTION AND ICT LITERACY ON MICRO, SMALL, AND MEDIUM ENTERPRISES'S PERFORMANCE
}

\author{
Dewi Kusuma Wardani ${ }^{1}$, Laurensia Claudia Pratomo ${ }^{2}$ and Riska Wulandari ${ }^{3}$ \\ ${ }^{123}$ Postgraduate of Economic Education Department, Universitas Sebelas Maret, \\ Surakarta, Indonesia
}

DOI: http://dx.doi.org/10.37500/IJESSR.2022.5103

\begin{abstract}
This study aims to determine the effects of (1) ICT adoption and ICT literacy simultaneously, (2) ICT adoption, and (3) ICT literacy on MSME's performance. Using the quantitative method, this study involved 30 MSME's in Surakarta as the research object. The data were obtained by distributing questionnaires to MSME owners before being processed using the SPSS Statistics 23 application. The results of data processing showed that (1) ICT adoption and ICT literacy simultaneously has a significant effect on MSME's performance, (2) ICT adoption has a significant effect on MSME's performance, and (3) ICT literacy has a significant effect on MSME's performance.
\end{abstract}

KEYWORDS: Information and communication technologies, ICT adoption, ICT Literacy, MSME's performance.

\section{INTRODUCTION}

The rapid development of information technology (IT) has triggered the realization of the industrial revolution 4.0, which allows for unlimited interactions and disrupts various fields of human life. Business sectors experience fundamental changes by utilizing digital technology that minimizes the cost structure, increases efficiency, and expands marketing reach. Various marketplaces are offered such as Go-Jek, Grab, Shopee, Bukalapak, and Tokopedia. Business competition is very competitive, so IT adaptation, innovation, creativity, efficiency, and differentiation are needed.

The COVID-19 pandemic that is faced by almost all countries in the world, including Indonesia, has restricted physical human activity, decreased public health, and increased the death tolls. The government establishes a policy of studying from home, working from home, the level of emergency in an area based on the number of residents exposed to COVID-19, and a ban on travel at the specified time. Restrictions on people's physical mobility have decreased aggregate demand and supply. Micro, Small, and Medium Enterprises (MSME's) have had a significant decrease in income which has an impact on the welfare of the workforce. MSME's still have limited abilities to use IT (digital media). The use of It will fundamentally encourage the improvement of MSME business and performance. It is necessary to adopt IT for MSME's to compete in a very competitive market and maintain business 
sustainability because adopting ICT provides many possibilities for MSME's to acquire other skills and knowledge (Mabula, J. B., \& Ping, H. D., 2018), including applying it in business practices such as the use of websites and e-commerce to reach new and strong markets in competition. However, the IT adoption of MSMEs is influenced by the readiness of MSME actors and their workforce.

Digital literacy is the cohesion, action, and skills in utilizing and interpreting digital technology to manage, reach, evaluate information, integrate, analyze, create, communicate, and build new knowledge among individuals to play a more effective role in the community (Widyastuti, 2007). 2016). Digital literacy teaches the use of digital-based technology that is not only introducing but also aligning it with daily activities which will have an impact on increasing productivity (Damayanti, Sandy, Albaab, Firmansyah, 2021). Digitally literate MSME's will anticipate a decrease in physical (retail) sales to e-commerce, thereby reducing the risk of diminishing profits.

Awareness of using technology, government support, management, and financial capabilities are factors that influence the adoption of technology by MSME's (Sani et al., 2020). Dissemination of information, education, and training as well as assisting the adoption of technology and digital literacy from stakeholders will encourage the use of IT in MSME organizations.

Consoli's study (2012) shows the impact of ICT adoption on MSME's performance, especially in terms of data integration, software updates in management, and system changes that lead to productive MSME's performance. Another study from Tarutè and Gatautis (2014) explained the importance of ICT adoption as a means of business competition and MSME's performance, including increasing efficiency, improving relationships with customers and suppliers, and expanding business opportunities. Unfortunately, ICT adoption is considered to have no effect on MSME's performance (Omiunu, 2019), especially MSME's owned by women. The limited infrastructure and less ability to use ICT is the determining factor because the adopted ICT will be an obstacle to MSME's performance when they are not familiar with the use of ICT.

The findings of Kulathunga, K. M. M. C. B., Ye, J., Sharma, S., \& Weerathunga, P. R. (2020), and Mabula, J. B., \& Ping, H. D., (2018) show that technological literacy has a positive effect on the performance of MSME's. In addition, Omiunu's research (2019) shows the impact of ICT literacy on MSME's performance. When someone has ICT literacy, he or she can develop various related skills in optimizing the use of ICT including skills in understanding, using, modifying, and creating MSME content and services. The results of this study are expected to provide information to MSME's, the government, and universities regarding the importance of ICT adoption and literacy on MSME's performance. 


\section{International Journal of Education and Social Science Research}

Vol. 5, Issue.1, Jan-Feb 2022, p no. 21-33

\section{LITERATURE REVIEW}

\subsection{Micro, Small, and Medium Enterprises (MSMEs)}

Micro, Small, and Medium Enterprises (MSMEs) are standalone productive businesses, both individuals and business entities in the community. The Ministry of Communication and Information (2021) reports that the number of MSMEs in Indonesia reaches 64.2 million in 2021. Currently, MSMEs contribute to GDP (Gross Domestic Product) of $61.07 \%$ or Rp8,573.89 trillion. Most business forms are MSMEs which have a large and important contribution to the macroeconomy. MSMEs make a dominant contribution from business entities in Indonesia of around 99\%. They absorb about 97\% of the total workforce and collect about $60.42 \%$ of the total investment in Indonesia (Ministry of Communication and Information Technology, 2021).

The criteria for MSMEs according to the Central Statistics Agency (BPS) include (1) micro-businesses with 1 to 5 employees, (2) small businesses with 5 to 19 employees, and (3) medium businesses with 20 to 99 employees (Ministry of Finance, 2012).

According to Law Number 20 of 2008 concerning Micro, Small, and Medium Enterprises (MSMEs), the criteria for MSMEs include

2.1.1. Micro-businesses that have net assets (excluding land and buildings of business premises) of $\leq$ Rp50,000,000 (fifty million rupiahs) or annual sales proceeds of Rp300,000,000 (three hundred million rupiahs),

2.1.2. Small businesses with net assets (excluding land and building for business premises) of > Rp50,000,000 (fifty million rupiahs) to Rp500,000,000 (five hundred million rupiahs) or annual sales proceeds > Rp300,000,000 (three hundred million rupiahs) to Rp2,500,000,000 (two billion five hundred million rupiahs), and

2.1.3. Medium businesses that have net assets (excluding land and buildings of business premises) of $>$ Rp500,000,000 (five hundred million rupiahs) to Rp10,000,000,000 (ten billion rupiahs) or annual sales proceeds of $>$ Rp2,500,000,000 (two billion five hundred million rupiahs) to Rp50,000,000,000 (fifty billion rupiahs). 


\begin{tabular}{lll} 
& \multicolumn{2}{c}{ Table 1: The Criteria for MSME } \\
\hline MSME Type & $\begin{array}{c}\text { Net Asset (Except Land and } \\
\text { Buildings of Business Premises) }\end{array}$ & Turnover/year \\
& $\leq$ Rp50 million & $\leq$ Rp300 million \\
Micro & $>$ Rp50 million to Rp500 million & $>$ Rp300 million to Rp2.5 billion \\
Small & Pp500 million to Rp10 billion & $>$ Rp2.5 billion to Rp50 billion \\
Medium & & \\
\hline
\end{tabular}

\subsection{ICT Literacy}

Digitalization has brought a lot of changes in patterns and ways of working. The presence of technology has affected large- and micro-scale businesses. This change requires MSMEs to adjust to maintain their businesses and develop them. ICT literacy is an initial aspect to be considered and measured for MSMEs to enter and adapt to the digitalization era. Omiunu (2019) defines the concept of ICT literacy as e-literacy, which refers to the ICT tools used in adopting ICT. In this case, ICT literacy refers to the ability to operate ICT devices. ICT literacy consists of several indicators, namely information literacy, technological literacy, computer literacy, digital literacy, media literacy, and visual literacy (Omiunu, 2019).

First, information literacy is the ability to find and evaluate information and use it effectively. Second, technological literacy is knowledge about technology in terms of its definition, purpose, application, efficiency, and effectiveness. Third, computer literacy is knowledge about computers and devices and their operations. Fourth, digital literacy is the ability to use digital devices. Fifth, media literacy is the ability to access, understand, interpret, and evaluate the meaning of information conveyed through the media, as well as create and communicate information through the media. Sixth, visual literacy is the ability to understand, interpret, use, or create visual messages such as images and videos (Lemke, 2003; Omiunu, 2019).

Disruption has had a major impact on shifting patterns of strategy and business opportunities, including MSMEs. Business opportunities are expanding with new challenges. These new challenges for MSMEs in the digitalization era are related to ICT. ICT literacy is the focus that MSMEs need to consider maintaining their current business. Research related to MSME ICT literacy has received great attention in this digitalization era. However, not much literature discusses ICT literacy and its impact on MSME's performance.

The study of Kulathunga, K. M. M. C. B., Ye, J., Sharma, S., \& Weerathunga, P. R. (2020) shows that technological literacy greatly affects technology adoption in MSME's. Technology adoption is an important resource in expanding a business that cannot be separated from technological literacy from business owners. MSME owners must also understand the advantages and role of technological 
Vol. 5, Issue.1, Jan-Feb 2022, p no. 21-33

literacy in improving the performance of MSMEs. The results of Omiunu's research (2019) reveal that ICT literacy has a significant effect on ICT adoption to improve MSME's performance. This study investigates ICT literacy which moderates ICT adoption and MSME's performance. This confirms that ICT literacy is one factor that contributes to the relationship between ICT adoption and the improved performance of MSMEs. In addition, Baker and Lomax (in Omiunu, 2019) reveal that digital literacy (e-literacy) can improve business performance. This shows that ICT literacy is important and has a role as well as an impact on the performance of MSMEs so that it needs to be measured, evaluated, and improved.

\subsection{ICT Adoption}

ICT adoption is very much needed and crucial in the current era of digitalization. Technology has disrupted many aspects of life. MSMEs must begin to accept, adapt, and adopt ICT to maintain and develop businesses. The efficiency and effectiveness of the MSME business are a necessity that drives the need for ICT adoption. ICT is important and useful in managing information, selling, and marketing products. Olise et al. (2014) define ICT as a technical means used to facilitate access, communication, and transmission of information through digital devices. ICT adoption is necessary for MSMEs (Tarute \& Gatautis, 2014) as a condition or process in the adjustment and use of ICT in business.

ICT adoption is determined by two factors, namely organizational and individual. Organizational factors include company size, HR capital, organizational culture, and job involvement while the individual factors are determined by the owner's commitment, personality traits, culture in information systems, skills, and learning by doing processes. Consoli (2012) who analyzed the literature related to ICT adoption identified that the determinants of ICT adoption include organizational and individual factors in addition to technological, economic, and environmental factors.

Organizational factors have a considerable influence on the readiness of MSMEs to adopt ICT (Nair, Chellasamy, \& Singh, 2019). Changes in the organizational structure are related to the pattern of ICT adoption (Fabiani, Schivardi, \& Trento, 2005). The size of MSMEs is a facilitator in organizational readiness to adopt ICT (Nair, Chellasamy, \& Singh, 2019) and has a positive effect on ICT adoption (Fabiani, Schivardi, \& Trento, 2005; García-Moreno, 2016). HR capital and job involvement are also positively related to ICT adoption (Fabiani, Schivardi, \& Trento, 2005). High-quality human resources and job involvement are more likely to adapt to technological changes and adopt ICT. Meanwhile, organizational culture is an important component of organizational factors in achieving MSME's performance (Tidor et al., 2012).

Individual factors also influence the level of ICT adoption (Consoli, 2012). Managerial commitment is important in the successful adoption of ICT and implementation of e-business (Damaskopoulos \& Evgeniou, 2003). Greater top management commitment tends to support the level of new technology adoption and e-business implementation (García-Moreno, 2016). Personality trait factors are related to the level of ICT adoption. Reynolds et al. (2020) found that executive personality traits correlate 
with technology adoption. Furthermore, personality traits show a positive relationship with MSME business performance (Ranawaka \& Samarakoon, 2020). Meanwhile, cultural factors in information systems reflected by values play an important role in determining the pattern of ICT adoption and development (Leidner \& Kayworth, 2006). The skills factor also shows an important role in ICT adoption (Fabiani, Schivardi, \& Trento, 2005). In addition, learning by doing processes is also a determinant of technology adoption at the individual level (Consoli, 2012).

Several studies (Bayo-Moriones, Billon, \& Lera-Lopez, 2013; Mesároš \& Mandičák, 2017; Olise et al., 2014; Tarutè and Gatautis, 2014; Tsambou \& Kamga, 2017) report that ICT adoption is important and has an impact on MSME's performance. The impact of ICT adoption occurs after the period of ICT adoption (Consoli, 2012) which is classified into four groups, namely performance, growth, expansion, and new products. Bayo-Moriones, Billon, \& Lera-Lopez (2013) revealed that the longer the adoption of ICT has been implemented, the greater the positive impact of ICT can be.

Tarute and Gatautis (2014) reviewed the literature on the direct and indirect impacts of ICT adoption on MSME's performance. Based on the summary of the previous findings, ICT adoption can increase productivity, sales, profit, market value and share, organizational expansion, efficiency, effectiveness, social and environmental performance, and competitiveness of MSME's. Empirical studies have confirmed the evidence on the positive impact of ICT on MSME's performance. Mesároš \& Mandičák (2017) clarified that ICT also influences company performance. The findings reveal that the ICT investment made by the company has an impact on increasing the company's performance in terms of reducing costs and profits.

Olise et al. (2014) highlight the impact of ICT adoption on MSME's performance in Nigeria. The impact of ICT on the MSME's performance was analyzed with the production function. This study found that ICT adoption was influenced by the capital base, turnover, and asset value. ICT adoption was also found to increase output performance as capital increased. This tends to indicate an increase in productivity due to ICT adoption. In addition, it was indicated that MSME's performance also increased because of MSME characteristics such as MSME size, capital, income, asset value, and the number of employees.

Tsambou \& Kamga (2017) studied the relationship between ICT and the MSME's performance in Cameroon. This study found that the adoption of ICT in synergy with innovation had a positive impact on improving the MSME's performance. This can be explained through the benefits of ICT which offers efficiency and effectiveness, and the synergy between ICT and innovation that can improve the performance of MSMEs. The findings of the study confirm that ICT adoption with innovation activities carried out by MSMEs encourages MSME's performance to increase.

The findings of Bayo-Moriones, Billon, \& Lera-Lopez (2013) confirm that there is a positive relationship between ICT adoption and MSME's performance in the short and long term. However, the findings reveal that the direct impact of ICT on both operational performance and final performance 
Vol. 5, Issue.1, Jan-Feb 2022, p no. 21-33

is still limited. The positive impact of ICT is not necessarily a direct impact, which is caused by different types of ICT adopted and the backwardness of ICT adoption.

Contrary to the above findings, Omiunu (2019) examining the performance of women-owned MSMEs in Nigeria found that ICT adoption had no significant relationship with the performance of MSMEs because the ICT adoption is still growing. In this case, the MSME's performance has not reflected the optimal use of ICT. Tsambou \& Kamga (2017) also found that the negative effect of ICT capacity (as measured by ICT investment) on the MSME's performance globally was significant, especially in the secondary industry mainly because new skills are needed in adopting ICT so that it is not necessarily efficient for MSMEs. Meanwhile, most MSMEs in Cameroon still use family labor. This further shows that the ICT adoption by MSMEs in developing countries is still experiencing delays with lower ICT penetration rates than in developed countries so that the impact on MSME's performance is still minor.

\subsection{MSME's Performance}

The measurement of the MSME's performance has attracted a lot of interest and attention and has been researched with many findings. Company performance is defined as the level of achievement of company goals (Mahmudova, \& Kovács, 2018). Santo \& Brito (2012) define company performance as an outcome or result that includes financial and operational aspects. The company performance is part of the effectiveness of the organization. In this case, the MSME's performance is the results achieved by MSMEs, including financial and operational.

Improved performance is a parameter of the success of MSMEs. Performance growth tends to be crucial to measure and evaluate for MSMEs. MSMEs that contribute greatly to the macroeconomy and support most gross domestic products are expected to survive and continue to grow. Thus, improving the performance of MSMEs will also have an impact on the national and global economy. A lot of literature examines MSME's performance. The company performance advantage reflects the company's competitive advantage (Muafi \& Roostika, 2014). Thus, the good performance of MSMEs also reflects the conditions and competitive advantages of the MSME business. Besides, performance indicators help improve the results (Mahmudova \& Kovács, 2018).

MSME's performance according to the literature is measured by financial and operational performance. However, Bayo-Moriones, Billon, \& Lera-Lopez (2013) state the term financial performance as final performance while Santo \& Brito (2012) state the term operational performance as strategic performance. Chairoel, Widyarto, \& Pujani (2015) suggest that operational performance means performance related to business processes while financial performance is related to financial performance and capacity in market domination.

Operational performance is reflected in reducing costs, productivity, product development and product quality, satisfaction, and service (Bayo-Moriones, Billon, \& Lera-Lopez, 2013; Chairoel, Widyarto \& Pujani, 2015; Mahmudova \& Kovács, 2018). Meanwhile, financial performance is related to sales 
growth, profit, margin, and market share (Bayo-Moriones et al., 2013; Chairoel, Widyarto \& Pujani, 2015; Mahmudova \& Kovács, 2018). However, Santo \& Brito (2012) put forward performance measures more clearly through financial performance which includes profitability, growth, and market value; and strategic (operational) performance includes employee satisfaction, customer satisfaction, environmental performance, and social performance.

Bayo-Moriones, Billon, \& Lera-Lopez (2013) found that ICT resources had a positive relationship to MSME's performance, both operational and final performance. Chairoel, Widyarto, \& Pujani (2015) found a lot of empirical evidence that the positive impact of ICT on operational performance in the short term will increase efficiency, customer satisfaction, and business development. It also influences long-term financial performance related to profit and market value.

MSME's performance in this study was measured by profitability, growth, market value, customer satisfaction, employee satisfaction, environmental performance, and social performance.

Table 2. MSME's performance Measure Indicators

\begin{tabular}{|c|c|}
\hline Dimensions & Indicator \\
\hline Profitability & $\begin{array}{l}\text { Net profit/income, Addition of machines, Addition of } \\
\text { inventory }\end{array}$ \\
\hline Growth & $\begin{array}{l}\text { Growth in the number of employees, Business } \\
\text { expansion }\end{array}$ \\
\hline Market value & Net income growth \\
\hline Customer satisfaction & $\begin{array}{l}\text { Repurchase rate, Increase in new customers, Customer } \\
\text { satisfaction }\end{array}$ \\
\hline Employee satisfaction & $\begin{array}{l}\text { Increased production, Increased sales, Employee } \\
\text { satisfaction }\end{array}$ \\
\hline Environmental performance & Reducing paper and plastic usage, Reuse of residue \\
\hline Social performance & Business license, Acceptance of company policy \\
\hline
\end{tabular}

Improving MSME's performance is very important for MSMEs to maintain and develop their businesses. Mahmudova \& Kovács (2018) state that measuring company performance is very important because performance will be a major pillar of business as a business strength. In addition, the company performance is also evaluated from many perspectives. Therefore, improving the MSME's performance will have a great impact.

\section{RESEARCH PURPOSE}

This study aims to determine the effects of (1) ICT adoption and ICT literacy simultaneously, (2) ICT adoption on MSME's performance, and (3) ICT literacy on MSME's performance. 


\section{RESEARCH METHOD}

In this study, the quantitative method was used by distributing questionnaires to 30 MSME's owners. This Likert-scale questionnaire has 4 scales from Strongly Agree (4) to Strongly Disagree (1), and the data were tested using the SPSS 23 program. The results of multiple regression analysis, F-test, and ttest were used to determine the effect of ICT adoption and ICT literacy simultaneously on MSME's performance and the effect of ICT adoption and ICT literacy on MSME's performance partially.

\section{DATA PROCESSING RESULTS}

The prerequisite tests consisted of validity and reliability tests. Validity test was used to determine the accuracy of the instrument used in measuring the variables of this study, namely ICT adoption, ICT literacy, and MSME's performance. The validity of the instrument used the Pearson formula and obtained $\mathrm{R}>\mathrm{R}$ table with a sample size of 30 at a significant level of $5 \%, \mathrm{R}=0.361$, and the value of Sig (2-tailed) of $<0.05$; based on the description, the item was considered valid because it met the requirements. Reliability test aims to make sure that the accuracy of the instrument in each measurement is consistent. This study looks at the value of Cronbach's Alpha in each research variable provided that the value is $>0.60$. Cronbach's Alpha value on the ICT adoption was 0.948, ICT literacy 0.946, and MSME's performance 0.98. It can be concluded that ICT adoption, ICT literacy, and MSME's performance have a Cronbach's Alpha value of more than 0.60.

Furthermore, the multiple regression analysis prerequisite test was conducted. The results of the normality test showed the value of Sig (2-tailed) of $0.200>0.05$, so the ICT adoption, ICT literacy, and MSME's performance met the assumptions and were normally distributed. The results of the multicollinearity test showed that all research variables had a tolerance value of $>0.10$ and a VIF value of $<10.00$; for the ICT Literacy variable, the tolerance value was $0.650>0.10$ and the VIF value of $1.538<10.00$ while the ICT Adoption variable had a tolerance value of $0.650>0.10$ and a VIF value of $1.538<10.00$. Based on this, the research data has met the assumption of correlation between variables. In addition, the Scatterplot graph showed that the data were circular and not patterned, which means that there was a linear relationship between the research variables.

After the analysis prerequisite test and multiple regression analysis prerequisite test were carried out, the hypothesis test results were calculated. Multiple regression analysis was used to determine the relationship between the independent variables (ICT adoption and ICT literacy) and the dependent variable (MSME's performance). The results of the multiple regression test showed the value of $\mathrm{Y}=$ $4.756+0.187 \mathrm{X} 1+0.585 \mathrm{X} 2$. Based on this equation, the constant value (a) is 4.756 , which means that the ICT adoption and ICT literacy variables are in a constant state, so MSME's performance is 4.756 units. The value of $\mathrm{b} 1$ is 0.187 , meaning that, if the ICT adoption variable increases by 1 unit, MSME's performance will increase by 0.187 . units. Meanwhile, the value of b2 is 0.585 , which means that, if the ICT literacy variable increases by 1 unit, MSME's performance will increase by 0.586 units. Correlation analysis was used to determine the closeness of ICT adoption and ICT literacy with MSME's performance. It is known that the correlation $\mathrm{R}$ value is 0.903 which is significant at $\square=$ 
Vol. 5, Issue.1, Jan-Feb 2022, p no. 21-33

0.05. This shows that there is a very strong and significant relationship between the variables of ICT adoption and ICT literacy with MSME's performance. The coefficient of determination in this study was used to determine the contribution of ICT adoption and ICT literacy in explaining the dependent variable, MSME's performance. The value of the coefficient of determination ( $\mathrm{R}$ square) is 0.816 (81.6). This shows that the variation of the dependent variable, MSME's performance (Y), can be explained by the ICT adoption and ICT literacy by $81.6 \%$ while the rest is explained by other variables outside of this study.

The F test was conducted to determine the effect of simultaneous ICT adoption and ICT literacy on MSME's performance. The test was conducted simultaneously using the F distribution by comparing the $\mathrm{F}$ value with the value of $\mathrm{F}$ table. The results of data processing showed $\mathrm{F}>\mathrm{F}$ table $(62.137>$ 3.354 ) with the probability value in the Sig, column of 0.000 , and the value was less than 0.05 . Thus, there was a significant influence between ICT adoption and ICT literacy simultaneously on MSME's performance. The t-test was conducted to determine the effect of ICT adoption and ICT literacy on MSME's performance partially. The results of data processing showed that the $t$ value of the ICT adoption variable was 3.321, greater than the value of t table of 2.048, and the value of Sig. was 0.000 $<0.05$; meanwhile, the $t$ value of the ICT literacy was 6.615, greater than the value of $t$ table of 2.048, and the value of Sig. was $0.000<0.05$. Therefore, ICT adoption and ICT literacy had a significant effect on MSME's performance.

\section{DISCUSSION}

The results of data processing showed $\mathrm{F}>\mathrm{F}$ table $(62.137>3.354)$ with the probability value in the Sig, column of 0.000 , and the value was less than 0.05 . Thus, there was a significant influence between ICT adoption and ICT literacy simultaneously on MSME's performance. The $t$ value of the ICT adoption variable was 3.321, greater than the value of $t$ table of 2.048, and the value of Sig. was 0.000 $<0.05$; meanwhile, the $t$ value of the ICT literacy was 6.615, greater than the value of t table of 2.048, and the value of Sig. was $0.000<0.05$. Therefore, ICT adoption and ICT literacy had a significant effect on MSME's performance. It means that (1) ICT adoption and ICT literacy simultaneously has a significant effect on MSME's performance, (2) ICT adoption has a significant effect on MSME's performance, and (3) ICT literacy has a significant effect on MSME's performance.

The adoption in MSME's occurs due to various stimuli (Consoli, 2012) including business conditions, organizational conditions (including all workers, management, and employers), and management conditions (skilled resources). The adoption of ICT is an important factor, so MSME's should consider ICT as an important tool in business activities and competition. When they decide to adopt ICT, the impact will be extraordinary (Consoli, 2012); it stimulates MSME's to invest in new technology because ICT adoption affects competitive advantage and MSME's performance. However, to benefit from ICT adoption, MSME's need to pay attention to several important requirements (Tarute and Gatautis, 2014) including infrastructure, skilled human resources, and ICT investment budget. When these three conditions have been met, MSME's can improve service quality as well as explore new 
business opportunities. MSME's can learn to use ICT in various ways (Omiunu, 2019) as follows: (a) MSME's owners and the government hold training and workshops that provide facilities for SME owners and their employees to improve MSME's performance through ICT skills and literacy; (b) nongovernmental organizations and the government can provide capital and financial assistance to support MSME's in adopting ICT so that the training received by SMEs can be maximized, especially its longterm impact on MSME's performance; (c) non-governmental organizations and the government can provide direct assistance in the form of ICT equipment and tools needed by the community such as computers, software, and others for ICT adoption training. A liaison is needed to bridge the ICT adoption process to MSME's performance, namely ICT literacy. This ICT literacy affects how MSME owners use ICT in their business. When MSME's only adopt ICT without being ICT literacy, there will be no alignment between the business strategies used and the goals to be achieved by MSME's (Omiunu, 2019), one of which is the use of ICT to optimize MSME's performance.

\section{CONCLUSION}

Based on the discussion, there are positive and significant effects of ICT adoption and ICT literacy, ICT adoption, and ICT literacy on MSME's performance. Collaboration and synergy between MSME owners and the government are needed in optimizing ICT adoption to improve MSME's performance in the form of capital assistance, costs, or ICT supporting equipment. Universities can also participate in MSME's training and workshops as a form of higher education's tri dharma (the three pillars) in delivering the knowledge to improve ICT literacy and MSME's performance to be more competitive and efficient.

Further research can discuss the readiness of MSME's in ICT adoption to fully examine the impact and benefits of technology in MSME's performance. In addition, the researchers also suggest examining training and workshops for MSME's that optimize the use of ICT to improve MSME's performance, such as the models and approaches used.

\section{REFERENCES}

Bayo-Moriones, A., Billon, M., \& Lera-Lopez, F. (2013). Perceived performance effects of ICT in manufacturing SMEs. Industrial Management \& Data Systems, 113(1), 117-135. http://dx.doi.org/10.1108/02635571311289700.

Chairoel, L., Widyarto, S., \& Pujani, V. (2015). ICT adoption in affecting organizational performance among Indonesian SMEs. The International Technology Management Review, 5(2), 82-93. https://doi.org/10.2991/itmr.2015.5.2.3.

Consoli, D. (2012). Literature analysis on determinant factors and the impact of ICT in SMEs. Procedia-social and behavioral sciences, 62, 93-97. https://doi.org/10.1093/icc/dth050. 
Vol. 5, Issue.1, Jan-Feb 2022, p no. 21-33

Damaskopoulos, P. \& Evgeniou, T. (2003). Adoption of new economy practices by SMEs in Eastern Europe. European Management Journal, 21(2), 133-145. https://doi.org/10.1016/S02632373(03)00009-4.

Fabiani, S., Schivardi, F., \& Trento, S. (2005). ICT adoption in italian manufacturing: firm level evidence. Industrial and Corporate Change, 14(2), 225-249. https://doi.org/10.1093/icc/dth050.

García-Moreno, M. B., García-Moreno, S., Nájera-Sánchez, J. J., \& de Pablos Heredero, C. (2016). An explanatory model of the organizational factors that explain the adoption of e-business. Journal of Industrial Engineering and Management (JIEM), 9(2), 547-581. http://dx.doi.org/10.3926/jiem.1917.

Kementerian Keuangan. (2012). Kebijakan Antisipasi Krisis Tahun 2012 Melalui Program Kredit Usaha Rakyat. Retrieved October 17, 2021, from https://kemenkeu.go.id/sites/default/ files/laporan_tim_kajian_kebijakan_antisipasi_krisis_tahun_2012_melalui_kur.pdf.

Kementerian Komunikasi dan Informatika. (2021). Pemerintah Terus Perkuat UMKM Melalui Berbagai Bentuk Bantuan. Retrieved October 10, 2021, from https://www.kemenkeu.go. id

Kulathunga, K. M. M. C. B., Ye, J., Sharma, S., \& Weerathunga, P. R. (2020). How does technological and financial literacy influence SME performance: Mediating role of ERM practices. Information, 11(6), 297.

Leidner, D. E., \& Kayworth, T. (2006). A review of culture in information systems research: toward a theory of information technology culture conflict. MIS Quarterly, 30(2), 357-399. https://doi.org/10.2307/25148735.

Lemke, C. (2003). enGauge 21st century skills: literacy in the digital age. Retrieved October 19, 2021, from https://eric.ed.gov/?id=ED463753.

Mabula, J. B., \& Ping, H. D. (2018). Use of technology and financial literacy on SMEs practices and performance in developing economies. Int. J. Adv. Comput. Sci. Appl, 9(6), 74-82.

Mahmudova, L. \& Kovács, J. K. (2018). Definitining the performance of small and medium enterprises. Network Intelligence Studies, 6(12), 111-120. https://seaopenresearch.eu/ Journals/articles/NIS_12_5.pdf.

Mesároš, P. \& Mandičák, T. (2017). Impact of ICT on performance of construction companies in Slovakia. IOP Conf. Series: Materials Science and Engineering, 245, 1-9. https://doi.org/10.1088/1757-899X/245/7/072044.

Muafi \& Roostika, R. (2014). Organizational performance and competitive advantage determinants of creative SMEs. Journal of Corporate Governance, Insurance, and Risk Management (JCGIRM), 1(2), $1-19$. 
Vol. 5, Issue.1, Jan-Feb 2022, p no. 21-33

Nair, J., Chellasamy, A., \& Singh, B. N. B. (2019). Readiness factors for information technology adoption in SMEs: testing an exploratory model in an Indian context. Journal Of Asia Business Studies, 13(4), 694-718. https://doi.org/10.1108/JABS-09-2018-0254.

Olise, M. C., Anigbogu, T. U., Edoko, T. D., \& Okoli, M. I. (2014). Determinants of ICT adoption for improved SME's performance in Anambra State, Nigeria. American International Journal of Contemporary Research, 4(7), 163-176.

Omiunu, O. G. (2019). E-literacy-adoption model and performance of women-owned SMEs in Southwestern Nigeria. Journal of Global Entrepreneurship Research, 9(26), 1-19. Retrieved October 25, 2021, from https://doi.org/10.1186/s40497-019-0149-3.

Ranawaka, R.A.H.B. \& Samarakoon S.M.A.K. (2020). The impact of personality traits on the business performance of the small and medium enterprise in the Gampaha District Of Sri Lanka. International Journal of Advancements in Research \& Technology, 9(10), 17-27.

Reynolds, S., Cotrino, F., Ifedi, C., Donthu, N. (2020). An exploratory study of executive factors that lead to technology adoption in small Businesses. Journal of Small Business Strategy, 30(2),1-16.

Santos, J. B. \& Brito, L. A. L. (2012). Toward a subjective measurement model for firm performance. Brazilian Administration Review (BAR), 9(6), 95-117. http://dx.doi.org/10.1590/S1807$\underline{76922012000500007 .}$

Tarutè, A., \& Gatautis, R. (2014). ICT impact on SMEs performance. Procedia-social and Behavioral Sciences, 110, 1218-1225. https://doi.org/10.1016/j.sbspro.2013.12.968.

Tidor, A., Gelmereanu, C., Baru, P., \& Morar, L. (2012). Diagnosing organizational culture for SME performance. Procedia Economics and Finance, 3, 710-715. https://doi.org/10.1016/S2212$\underline{5671(12) 00218-3 .}$.

Tsambou, A. D. \& Kamga, B. F. (2017). Performance perspectives for small and medium enterprises in Cameroon: innovation and ICTs. Timisoara Journal of Economics and Business, 10(1), 68-87. https://doi.org/10.1515/tjeb-2017-0005.

UU Nomor 20 tahun 2008 tentang Usaha Mikro, Kecil, dan Menengah (UMKM). Wheeler, S. (2012). Digital Literacies for engagement in emerging online cultures. Retrieved October 19, 2021, from https://core.ac.uk/download/pdf/39139541.pdf. 